\title{
ICON-PENDANT WITH AN IMAGE OF THE SAINT WARRIOR-HORSEMAN FROM THE EXCAVATION OF THE MANGUP'S PALACE. OLD RUS' OR BYZANTIUM? ${ }^{1}$
}

\author{
Valery E. Naumenko \\ V.I. Vernadsky Crimean Federal University, Simferopol, Russian Federation
}

\begin{abstract}
Introduction. The article is devoted to the icon-pendant with the image of the horseman St. George the Warrior, discovered in 2020 in the cultural horizon of the late $13^{\text {th }}-14^{\text {th }}$ centuries at the research site of the Mangup's Princely Palace. Methods. The study is complex. The traditional methods of art history analysis and the method of analogies, widely used in archaeological science, are used in the description and attribution of the sign icon. The dating of the product is established using one of the most important stratigraphic methods in archaeology. In explaining the historical context of the find, the available data from archaeological and narrative sources on the history and culture of Mangup at the end of the $13^{\text {th }}-14^{\text {th }}$ centuries are used. Analysis. The value of the icon, in addition to its clear archaeological context and the iconographic type of the holy rider-triumphant, which is rare for Byzantine applied art, lies in the expansion of our source base on the spread of the cult of St. George in the Late Byzantine period of the history of South-Western Crimea, represented before that mainly by the churches of Eski-Kermen and Mangup. Results. Despite the general proximity of the iconography and the technique of making the Mangup find and numerous similar products from the territory of Old Rus, there is no reason to consider it as an icon-pendant of Ancient-Russian origin. The conducted research definitely indicates a weak study of this category of Christian objects of personal piety on the territory of Byzantium, the lack of their cataloging and the study of special issues. In this regard, the conclusion that the icon belongs to the number of finds of the Byzantine circle from the cultural layer of the Mangup settlement, made in one of the provincialbyzantine centers, seems to be the most objective.
\end{abstract}

Key words: Mangup fortress, palace, Byzantium, Old Rus', icon-pendant, holy warriors, St. George.

Citation. Naumenko V.E. Icon-Pendant with an Image of the Saint Warrior-Horseman from the Excavation of the Mangup's Palace. Old Rus' or Byzantium? Vestnik Volgogradskogo gosudarstvennogo universiteta. Seriya 4. Istoriya. Regionovedenie. Mezhdunarodnye otnosheniya [Science Journal of Volgograd State University. History. Area Studies. International Relations], 2021, vol. 26, no. 6, pp. 83-95. (in Russian). DOI: https://doi.org/10.15688/jvolsu4.2021.6.6

УДК 94; 902/904; 7.033

ББК 63.3(4); 63.4(3)
Дата поступления статьи: 01.06.2021

Дата принятия статьи: 08.11.2021

\section{ИКОНКА-ПРИВЕСКА С ИЗОБРАЖЕНИЕМ СВЯТОГО ВОИНА-ВСАДНИКА ИЗ РАСКОПОК МАНГУПСКОГО ДВОРЦА. ДРЕВНЯЯ РУСЬ ИЛИ ВИЗАНТИЯ? ${ }^{1}$}

\section{Валерий Евгеньевич Науменко}

Крымский федеральный университет им. В.И. Вернадского, г. Симферополь, Российская Федерация

\footnotetext{
Аннотация. Иконка-привеска с изображением конного св. Георгия-воина, обнаруженная в 2020 г. в культурном горизонте конца XIII - XIV в. на участке исследований Мангупского княжеского дворца, является важным источником по истории и культуре Мангупа для этого периода времени. Ценность иконки, помимо ее ясного археологического контекста и достаточно редкого для византийского прикладного искусства иконографического типа святого всадника-триумфатора, заключается в расширении нашей источниковой базы о распространении культа св. Георгия в поздневизантийский период истории Юго-Западного Крыма, представленного до этого в основном храмовыми комплексами Эски-Кермена и Мангупа. Несмотря на общую близость иконографии и техники изготовления мангупской находки и многочисленных однотипных изделий с территории Древней Руси, нет оснований рассматривать ее как иконку-привеску древнерусского
} 


\section{ВИЗАНТИЙСКАЯ ТАВРИКА}

происхождения. Проведенное исследование определенно указывает на слабую изученность данной категории христианских предметов личного благочестия на территории Византии, отсутствие их каталогизации и изучения специальных вопросов. В этой связи вывод о принадлежности иконки к числу находок византийского круга из культурного слоя Мангупского городища, изготовленных в одном из провинциально-византийских центров, представляется наиболее объективным.

Ключевые слова: Мангупское городище, дворец, Византия, Древняя Русь, иконка-привеска, святые воины, святой Георгий.

Цитирование. Науменко В. Е. Иконка-привеска с изображением святого Воина-всадника из раскопок Мангупского дворца. Древняя Русь или Византия? // Вестник Волгоградского государственного университета. Серия 4, История. Регионоведение. Международные отношения. - 2021. - Т. 26, № 6. - С. 83-95. DOI: https://doi.org/10.15688/jvolsu4.2021.6.6

Введение. С 2006 г. основным объектом раскопок Мангупского городища является дворец правителей княжества Феодоро 1425-1475 годов. К числу наиболее важных результатов его исследований, помимо установления точной хронологии и композиционно-художественного облика, относится открытие в стратиграфии археологического объекта ярусов застройки додворцового и постдворцового времени [6; 7]. Это свидетельствует об использовании данного участка городища на протяжении всех основных этапов его истории, в том числе в ранневизантийский (середина VI - конец VIII в.), фемный (середина IX - середина XI в.), золотоордынский (конец XIII в. - около 1395 г.), феодоритский (XV в., до 1475 г.) и османский (1475-1792 гг.) периоды, а также исключает «случайность» присутствия в культурном слое артефактов, на первый взгляд, не вписывающихся в общепринятый исторический или археологический контекст.

Многолетние раскопки дворца позволили получить целый массив новых археологических источников по истории и культуре Мангупа, который постепенно вводится в научный оборот. Среди них достойное место занимают находки из так называемой группы “small finds", характеризующие не только различные стороны повседневной жизни населения средневековой крепости, но и являющиеся зачастую основанием для рассмотрения малоизученных либо совершенно новых сюжетов из истории памятника.

К числу таких находок, безусловно, относится бронзовая иконка-привеска с изображением святого воина-всадника на аверсе и равноконечного креста на оборотной стороне, найденная в 2020 г. в ходе исследований Ман- гупского дворца. Иконка происходит из хорошо датированного культурного горизонта конца XIII - XIV в., связанного с функционированием поселения золотоордынского времени на месте будущей резиденции правителей княжества Феодоро, и пополняет коллекцию опубликованных в последнее время наиболее ярких предметов личного христианского благочестия из раскопок различных памятников городища $[4$, с. 355-358; 17; 20]. Однако ее неординарность состоит не только в этом.

В случае наиболее вероятной атрибуции изображения святого воина-всадника на лицевой стороне иконки св. Георгию Победоносцу она расширяет круг известных материальных свидетельств о культе этого святого на территории Юго-Западного Крыма в поздневизантийский период его истории, представленный, прежде всего, храмовыми комплексами Эски-Кермена (церковь «Трех всадников») и того же Мангупа (церковь св. Георгия) (о них см.: [21;28]).

Другая научная проблема, следующая из анализа нашей находки, заключается в констатации отсутствия надежных аналогий ей на памятниках Византии, в том числе в Византийской Таврике, и наличие близких, но не идентичных, многочисленных иконок-привесок с территории Древнерусского государства, особенно из Южной Руси. Означает ли это неизвестный по данным письменных источников факт миграции или миссионерской практики выходцев из Древней Руси в одном из крупных городских центров средневекового Крыма или все-таки речь идет о недостаточной степени изученности данной группы предметов личного восточно-христианского благочестия? Мы склоняемся к последнему варианту интерпретации поставленной 
научной проблемы, прежде всего, из-за отсутствия в литературе сводных корпусов подобных находок, происходящих с территории Византии и сопредельных областей. В таком случае мангупскую иконку следует по-прежнему рассматривать как находку византийского круга на городище, изготовленную, скоpeе всего, в одном из византийских провинциальных центров.

Методы. Исследование носит комплексный характер. При описании и атрибуции иконки-привески использованы традиционные методы искусствоведческого анализа, особенно в части интерпретации иконографического типа св. Георгия-воина на лицевой стороне иконки - образа святого всадника-триумфатора, и широко распространенный в археологической науке метод аналогий. Датировка изделия устанавливается с помощью одного из наиболее важных в археологии стратиграфического метода и анализа сопутствующего археологического материала.

При объяснении исторического контекста находки использованы имеющиеся на сегодняшний день данные археологических и нарративных источников по истории и культу- ре Мангупа в конце XIII - XIV в., когда городище, очевидно, находилось под контролем администрации Крымского улуса Золотой Орды, сохраняя при этом традиционные культурные, экономические и церковно-политические связи с Византией.

Описание и историко-археологический контекст находки. Бронзовая иконка состоит из почти круглой пластины диаметром около 3,00 см (точные размеры:

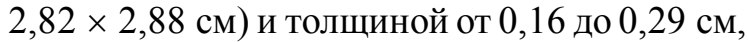
а также округлого ушка для подвешивания диаметром 0,67-0,68 м с внутренним каналом шириной до 0,20 см, отлитых с использованием восковой модели в глиняной или каменной двусторонней (разъемной) форме (см. рисунок) (о технологии изготовления подобных древнерусских иконок-привесок вкратце см.: $[26$, с. $9 ; 14$, с. 128 ; ср.: 23, с. 431]; см. также каменные формы для отливки однотипных византийских амулетов с изображением святых воинов-всадников: [32, с. 205, рис. 12, 1-2]). Степень проработанности деталей основных изображений и орнаментальных поясов изделия свидетельствует об их дополнительной гравировке после отливки.
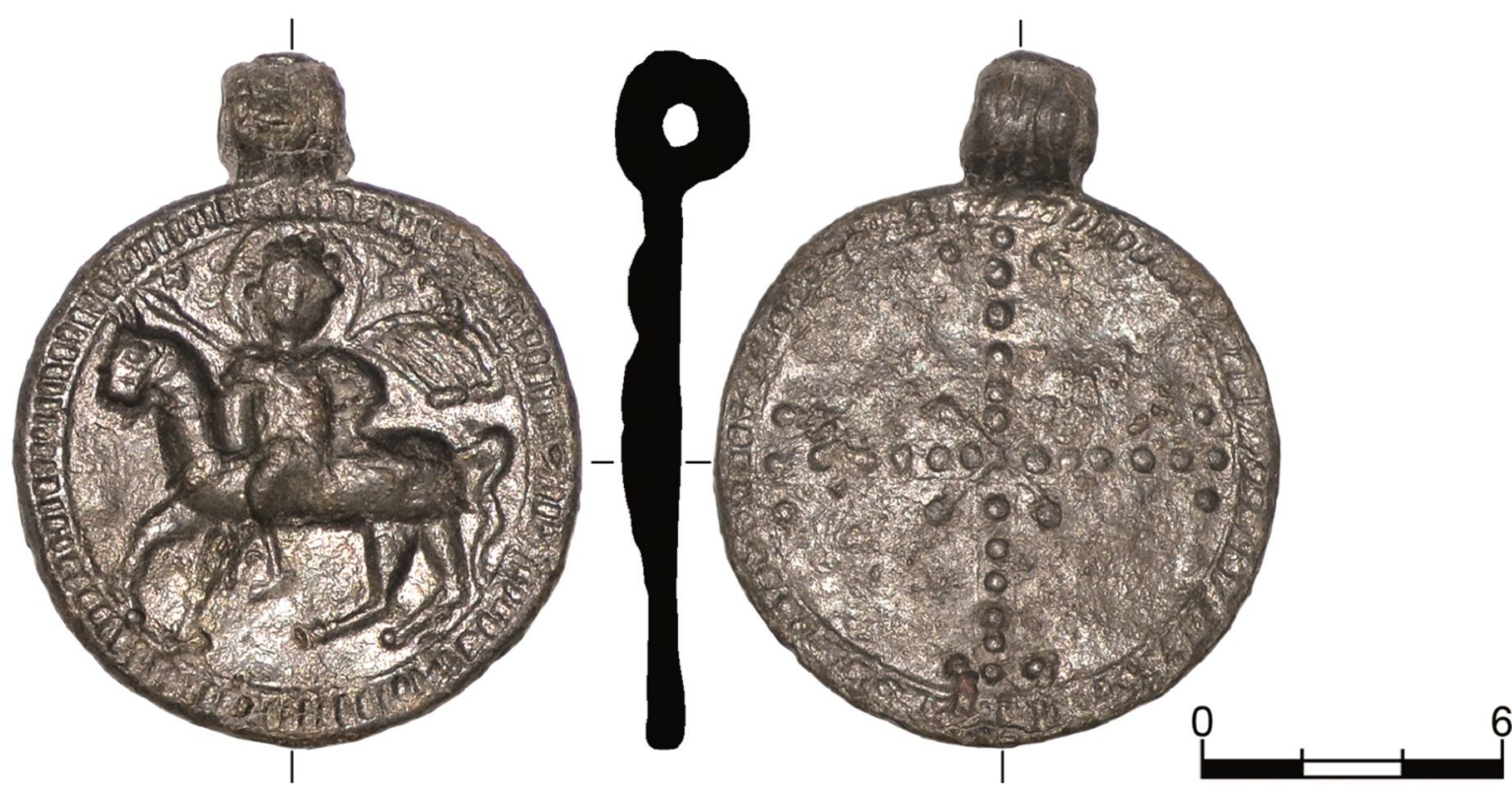

Бронзовая иконка-привеска с изображением конного св. Георгия-воина конца XIII - XIV в. из раскопок Мангупского княжеского дворца

(2020 г., Западный участок исследований, квадрат № 46, слой № 7)

Bronze icon-pendant with the image of the horseman St. George the Warrior of the late $13^{\text {th }}-14^{\text {th }}$ centuries from the excavations of the Prince's Palace of Mangup

(2020, Western research site, quadrant no. 46, layer no. 7) 


\section{ВИЗАНТИЙСКАЯ ТАВРИКА}

В целом находка имеет достаточно хорошую сохранность. Лишь ее наиболее рельефная часть - лицо и туловище святого воина-всадника на аверсе несет следы сильной потертости, что свидетельствует об использовании иконки владельцем по своему назначению может быть в течение нескольких лет.

Практически все поле лицевой стороны иконки занимает изображение святого конного воина-триумфатора влево в высоком рельефе, окруженное двойным «рубчатым» бордюром. Верхняя часть туловища воина обращена к зрителю практически анфас. Его голова - несоразмерно крупная, с округлыми глазами и прямоугольным носом, покрыта густой шапкой кудрявых волос в виде округлых локонов до уровня ушей и окружена нимбом. За спиной всадника развивается плащ, в правой руке он держит длинное копье с крупным наконечником под углом приблизительно в 45 градусов. Видимая левая нога конного воина, несоразмерно тонкая в голени, лишь слегка согнута в колене. Какие-либо детали одежды и амуниции всадника не просматриваются.

Лошадь также изображена без соблюдения реальных размеров и пропорций между ее отдельными частями. Слишком удлинены туловище и шея, анатомически неправильно показаны обе задние и левая передняя ноги. Судя по согнутой передней правой ноге и развивающимся хвосту и гриве лошади, а также плащу всадника, резчик пытался представить святого воина в движении, на гарцующем коне, что соответствует образу всадника-триумфатора. Однако, чтобы полностью воплотить этот замысел, ему явно не хватило опыта и мастерства. Лучше всего оказалась выполненной голова лошади с крупными глазами и видимыми уздечными ремнями. Остальные детали конской упряжи не просматриваются.

Слева и справа от нимба святого воинавсадника слабо видны две буквы - возможно, «А» и «Г», которые, если это прочтение верно, позволяют соотнести изображение на нашей иконке со св. Георгием Победоносцем. В таком случае надпись может быть дешиф-

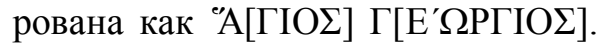

Оборотная сторона находки почти полностью занята равноконечным крестом с расширяющимися концами и хризмой вокруг средокрестья, выполненным крупными рельефными точками («жемчужинами») и окруженным таким же, как и на аверсе, «рубчатым» бордюром. Декорированию в виде рельефных продольных полос подверглась при изготовлении и оглавие (ушко для подвешивания) иконки.

В отличие от других опубликованных однотипных примеров византийской и древнерусской христианской металлопластики, о которых речь пойдет ниже, рассматриваемая иконка-привеска с предполагаемым изображением конного св. Георгия-триумфатора принадлежит к числу немногих находок, происходящих из культурного слоя археологического объекта и имеющих достаточно ясный историко-археологический контекст.

Она была обнаружена в 2020 г. на Западном участке исследований Мангупского княжеского дворца, в процессе выборки так называемого 7-го слоя на площади квадрата № 46, который сформировался в период функционирования поселения золотоордынского времени на месте будущей резиденции правителей княжества Феодоро 1425-1475 годов. Общая датировка культурного горизонта в пределах конца XIII - XIV в. (до 1395 г.) определяется стратиграфическими наблюдениями и структурой археологического комплекса находок этого времени на памятнике. Среди последних наиболее важными хроноиндикаторами выступают импортная глазурованная красноглиняная керамика византийского и золотоордынского круга групп «Elaborate Incised Ware», «Polichrome (Monochrome) Sgraffito Ware», «Slip-Painted Ware», золотоордынские кашинная посуда и бронзовые зеркала, а также монеты от ханов Тула-Буги (1287-1291) и Токты (1291-1313) до хана Тохтамыша (1379-1395) [5, с. 42-45; 6, c. $56 ; 8 ; 18$, с. $236-238]$.

При этом следует иметь в виду, что присутствие в культурном слое поселения золотоордынского времени христианской иконки, иконография которой следует общепринятой византийской традиции, не выглядит чем-то необычным для Мангупа этого исторического периода. Несмотря на контроль со стороны администрации Крымского юрта Улуса Джучи и даже присутствие ее представителей здесь, крепость на протяжении всего XIV в. продолжала сохранять стабильные культурные, экономические и церковно-политические связи с Византийской империей, в 
том числе как кафедральный центр Готской митрополии Константинопольского патриархата. С конца XIII в., как показывают результаты археологических исследований, она окончательно приобрела черты крупного поселения городского типа, топографическими доминантами которого на местности и в представлениях путешественников-современников выступали, помимо крепостных стен, общественных зданий и регулярной жилой застройки, многочисленные храмовые и монастырские комплексы с расположенными вблизи них христианскими некрополями [18; 19]. Другими словами, доминирование христианского, или даже шире, византийско-христианского компонента в материальной культуре Мангупского городища интересующего нас периода времени, подтверждается всем имеющимся комплексом нарративных и вещественных источников. В этот исторический контекст хорошо вписывается наша находка.

Анализ. С учетом ясной датировки и историко-археологического контекста мангупской иконки-привески дальнейший анализ будет в основном сосредоточен на вопросах ее происхождения. Еще раз подчеркнем, что при всей гипотетичности атрибуции изображения святого воина-всадника св. Георгию, основанной на плохо сохранившихся начальных буквах надписи и общей иконографии образа (безбородый юноша с густыми кудрявыми волосами в виде округлых локонов до уровня ушей), эта версия является достаточно вероятной.

Ввиду особой популярности культа св. Георгия в Византийской империи и в странах, где распространилось византийское православие, его история, агиографическая традиция, иконография представляются хорошо изученными в историографии, что избавляет нас от их подробного анализа (см.: $[1 ; 3 ; 11])$. Отметим лишь, что в Византийской империи с $\mathrm{X}$ в. он приобрел общегосударственный характер и составил, вместе с почитанием св. Димитрия Солунского, св. Феодора Тирона и св. Феодора Стратилата, основу общего культа святых воинов в империи, защитников от внешних врагов и внутренних демонов (наиболее важные работы об этом: [15; 38, p. 11-14, 57-124; 39, p. 32-93; 40, p. 41-144]).

Одновременно формируются и основные иконографические типы св. Георгия-воина в византийском искусстве - пешего воина в пол- ном вооружении (обычно в полный рост, анфас) и конного всадника с копьем (драконоборца или триумфатора на гарцующем коне). При этом важно заметить, что интересующий нас тип конного св. Георгия, драконоборца или триумфатора, окончательно складывается позднее образа св. Георгия - пешего воина, скорее всего, лишь к XII-XIII вв., и значительно реже встречается на памятниках прикладного искусства этого времени. Об этом свидетельствуют исследования данного вопроса в области сфрагистики $[27 ; 29 ; 33$, с. 52, 66; 36], камнерезного искусства [2, с. 279-282] и глиптики [37, p. 57, fig. 8] (о датировке литика с конным св. Георгием-драконоборцем см.: [9]).

Еще меньше примеров использования образа св. Георгия-всадника среди опубликованных материалов византийской металлопластики с христианской символикой. По сути, речь идет только об изданном в свое время В. Иванишевичем бронзовом медальоне (иконке с обломанным оглавием (?)) с изображением конного св. Георгия-триумфатора вправо, окруженном «рубчатым» бордюром, диаметром 2,6 см и толщиной 0,2 см, из коллекции Народного музея в Пожареваце (Cербия) [10, c. 49, 51, табл. II, 36]. Однако находка не имеет ясного археологического контекста и, соответственно, датировки. Скорее всего, эта ситуация объясняется отнюдь не редкостью таких изделий в византийской повседневной культовой практике, а обычным отсутствием на сегодняшний день специальных исследований и сводных корпусов подобных предметов личного благочестия в современной историографии, в отличие от каталогов металлических крестов, энколпионов, стеатитовых иконок, рельефов из слоновой кости и пр. (см. об этом: [30, с. 366]).

Круг аналогий иконке-привеске из раскопок Мангупа на памятниках Византийской Таврики выглядит также немногочисленным и сводится лишь к двум находкам. Первая из них происходит из подводных исследований в акватории Судакской бухты и поэтому не имеет ясного археологического контекста [13, c. 175 , рис. 185,1$]$, вторая обнаружена в пещерном христианском комплексе Иограф II вблизи вершины Ялтинской яйлы, в слое с перемешанным археологическим материалом от IX-X до XVIII вв. [31, с. 115 , рис. 36 


\section{ВИЗАНТИЙСКАЯ ТАВРИКА}

(к.о. 365)]. Изделия представляют собой круглые литые свинцовые (?) пластины с обломанными в древности ушками для подвешивания диаметром около 2,5 см, на лицевой стороне которых просматривается близкое нашей иконке изображение святого воина-всадника с копьем влево. К сожалению, обе находки имеют плохую сохранность и требуют серьезной реставрации. Из-за этого ничего определенного нельзя сказать в отношении материала, из которого они были изготовлены (свинец или все-таки оловянистая бронза?), и изображений на оборотной стороне. Предлагаемая авторами публикации атрибуция иконок св. Георгию также может быть принята лишь как предварительная гипотеза.

Тем не менее, как и в случае с памятниками Византии, редкость опубликованных иконок с изображением конного св. Георгия-воина с территории Крымского полуострова свидетельствует лишь о состоянии нашей источниковой базы для изучения этой категории археологического материала. Достаточно напомнить в этой связи, несмотря на очевидную разницу в датировках, размерах, технологии и иконографии, о медальонах-привесках VII-VIII вв. из двух штампованных бронзовых пластин с пастовым заполнением между ними из могильника Лучистое, с изображением св. Мины и святого всадника вправо, поражающего копьем демона (образ св. Соломона или св. Сисинния) [32, с. 147-150, рис. 1-2], о свинцовой (?) иконке-привеске святого воина-всадника с крестом на обороте, выполненным крупными рельефными точками («жемчужинами»), из храма на г. Пахкал-Кая IX/X-XIII/XIV вв. [12, c. 296, 298, рис. 4] или о бронзовых литых иконкаХ-привесках X-XI и XII-XIII вв. с изображениями соответственно Деисуса и Богоматери с младенцем из раскопок Херсонеса [16, c. 208-209, 498-499, № 146, 148], чтобы оценить степень влияния византийских традиций на использование в повседневной практике однотипных предметов личного христианского благочестия. К тому же некоторые из них (медальоны из Лучистого), как считается исследователями, изготавливались местным населением на основе образцов, завезенных непосредственно из Византии [32, с. 184].

Совершенно иная ситуация с поиском аналогий или, скорее, однотипных мангупской на- ходке иконок-привесок с изображением святого воина-всадника выглядит при обращении к памятникам Древней Руси главным образом домонгольского периода. К настоящему времени, в основном за последнее десятилетие, в научный оборот введены несколько десятков подобных бронзовых изделий, происходящих из раскопок археологических памятников, музейных собраний и частных коллекций на территории России, Белоруссии и Украины [26, с. 66, 135-136, табл. X, 145-149 (подгруппа IV.B); $35 ; 34 ; 22 ; 23 ; 24 ; 14$, с. 121-123, рис. 2, 5]. Резкое увеличение источниковой базы позволило провести систематизацию нового материала и выделить в нем, по крайней мере, два типа иконок, отличающихся своими размерами и иконографией святого всадника.

На иконках первого типа, диаметром около 3,5 см, на лицевой стороне представлена сцена «Чуда св. Георгия о Змие», развернутая вправо; святой всадник изображен в позе триумфа, почти анфас, с развевающимся плащом или без него, вонзающим высоко поднятое и зажатое в локтевом суставе копье непосредственно в пасть демона (основная работа: [23, ил. 65]). Иконография второго типа иконок-привесок несколько иная. Св. Георгийвсадник изображен здесь влево, как триумфатор на гарцующем коне и с развивающимся за спиной плащом, с высоко поднятым копьем и округлым щитом на левой ноге, без Змия; диаметр таких подвесок около 2,0 cм (см.: [35, рис. 2]).

Картографирование новых древнерусских иконок-привесок со святым всадником показывает, что изделия первого типа в основном были распространены на памятниках Северо-Западной и Северо-Восточной Руси, второго типа - в ареале Южной Руси, на территории Галицко-Волынского, Черниговского и Киевского княжеств, где они, вероятно, и производились. За пределами Руси они известны по археологическим и случайным находкам в Польше [41] и Латвии [25], что связывается с миссионерскими практиками древнерусских княжеств.

Общая хронология обоих типов иконок св. Георгия-всадника на Руси - в пределах второй половины XII-первой половины XIII века. Они рассматриваются как предметы личного благочестия, которые изготавливались в 
различных ремесленных центрах домонгольской Руси и использовались в повседневной жизни представителями различных социальных групп ее сельского и городского населения. Как справедливо отмечено, древнерусские иконки-образки, в том числе с изображением святого всадника (драконоборца или триумфатора), хотя и следуют общим принципам иконографии и художественных особенностей подобных изделий в византийской традиции, никогда не копируют византийскую металлопластику, и поэтому, в отличие от многих типов древнерусских нательных крестов этого времени, не имеют точных аналогий в византийском литье [14, с. 119].

Сопоставляя мангупскую иконку с изображением св. Георгия-всадника с однотипными изделиями с территории Древней Руси, прежде всего, южнорусских княжеств, нужно отметить их лишь самое общее сходство, проявившееся в выборе иконографического сюжета и технологии изготовления. В деталях отличия иконки из раскопок Мангупского дворца более существенны: высокий рельеф изображения; попытка тщательной и реалистичной его проработки на этапе моделирования и после отливки, хотя и не подкрепленная необходимым мастерством; принципиально иные способы декорирования основного изображения и реверса привески. Все это в целом не позволяет рассматривать ее как находку древнерусского происхождения, оказавшуюся в культурном слое городища в результате миграции или миссионерской практики ее обладателя. Скорее всего, речь идет об изделии византийского круга, изготовленном в одном из провинциальных центров Византии и затем приобретенном для личного пользования одним из жителей Мангупской крепости.

Результаты. Иконка-привеска с изображением конного св. Георгия-воина, обнаруженная в 2020 г. в культурном горизонте конца XIII - XIV в. на участке исследований Мангупского княжеского дворца, является важным источником по истории и культуре Мангупа для этого периода времени. Ценность иконки, помимо ее ясного археологического контекста и редкого для византийского прикладного искусства иконографического типа святого всадника-триумфатора, заключается в расширении нашей источниковой базы о распространении культа св. Георгия в поздневизантийский период истории Юго-Западного Крыма, представленного до этого в основном храмовыми комплексами Эски-Кермена и Мангупа.

Несмотря на общую близость иконографии и техники изготовления мангупской находки и многочисленных однотипных изделий с территории Древней Руси, у нас нет оснований рассматривать ее как иконку-привеску древнерусского происхождения. Проведенное исследование определенно указывает на слабую изученность данной категории христианских предметов личного благочестия на территории Византии, отсутствие их каталогизации и изучения специальных вопросов. В этой связи вывод о принадлежности иконки к числу находок византийского круга из культурного слоя Мангупского городища, изготовленных в одном из провинциально-византийских центров, представляется на сегодняшний день наиболее объективным.

\section{ПРИМЕЧАНИЕ}

${ }^{1}$ Исследование выполнено в рамках проекта РФФИ № 19-09-00124 «Дворцовый комплекс Мангупского городища - резиденция правителей княжества Феодоро в Юго-Западном Крыму. Проблемы хронологии, планировки и архитектурной реконструкции памятника». Выражаем признательность А.Г. Герцену, руководителю Мангупской археологической экспедиции ФГАОУ ВО «Крымский федеральный университет им. В.И. Вернадского», за возможность самостоятельной публикации находки.

The study was carried out within the framework of the project of Russian Foundation for Basic Research no. 19-09-00124 "The Palace complex of the Mangup fortress - the residence of the rulers of the principality of Theodoro in the South-Western Crimea. Problems of chronology, planning and architectural reconstruction of the monument". We express our gratitude to A.G. Gertsen, the leader of the Mangup archaeological expedition of the V.I. Vernadsky Crimean Federal university, for the possibility of independent publication of the find.

\section{СПИСОК ЛИТЕРАТУРЫ}

1. Алпатов, М. В. Образ Георгия-воина в искусстве Византии и Древней Руси / М. В. Алпатов 
// Труды Отдела древнерусской литературы. 1956. - T. XII. - C. 292-310.

2. Архипова, Е. И. Каменные иконки со святыми воинами : Византийское наследие и южнорусская традиция / Е. И. Архипова // Труды Государственного Эрмитажа. - 2015. - Т. 74 : Византия в контексте мировой культуры : материалы конф., посвящ. памяти А. В. Банк (1906-1984). - С. 271-289.

3. Атанасов, Г. Свети Георги Победоносец. Култ и образ в православния Изток през средновековието / Г. Атанасов. - Варна : Зограф, 2001. -443 с.

4. Герцен, А. Г. Древнерусские энколпионы из Юго-Западного Крыма / А. Г. Герцен, Т. Ю. Яшаева // Славяно-русское ювелирное дело и его истоки : материалы Междунар. науч. конф., посвящ. 100-летию со дня рождения Г. Ф. Корзухиной / ред.-сост. А. А. Пескова, О. А. Щеглова, А. Е. Мусин. - СПб. : Нестор-История, 2010. - С. 355-362.

5. Герцен, А. Г. «Между Золотой Ордой и Романией...». Великоханский вектор в культуре региональных элит или к вопросу о золотоордынском периоде в истории Мангупа середины - второй половины XIV в. (обзор археологических источников) / А. Г. Герцен, В. Е. Науменко // Крым в золотоордынский период. Крымский Юрт Золотой Орды : Наследие исчезнувшей империи : каталог выставки. Симферополь : Тарпан, 2016. - С. 36-49.

6. Герцен, А. Г. Княжеский дворец Мангупского городища. Стратиграфия участка исследований 2006-2017 гг. (предварительное сообщение) / А. Г. Герцен, В. Е. Науменко, А. А. Душенко // X Международный Византийский семинар

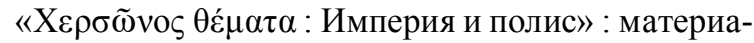
лы науч. конф. / отв. ред. Н. А. Алексеенко. - Севастополь : ИАК РАН, 2018. - С. 53-58.

7. Герцен, А. Г. Основные итоги и перспективы исследований княжеского дворца Мангупского городища / А. Г. Герцен, В. Е. Науменко, А. А. Душенко // XX Боспорские чтения «Боспор Киммерийский и варварский мир в период античности и средневековья. Основные итоги и перспективы исследований» : материалы Междунар. науч. конф. / ред.-сост. В. Н. Зинько, Е. А. Зинько. Симферополь ; Керчь : НИЦ ИАК КФУ : ЦАИ БФ «Деметра», 2019. - С. 139-148.

8. Душенко, А. А. Металлические зеркала из раскопок Мангупского княжеского дворца / А. А. Душенко // XXI Боспорские чтения «Боспор Киммерийский и варварский мир в период античности и средневековья. Объекты искусства в археологическом контексте» : материалы Междунар. науч. конф. / ред.-сост. В. Н. Зинько, Е. А. Зинько. Симферополь ; Керчь : НИЦ ИАК КФУ : ИАК РАН : ЦАИ БФ «Деметра», 2020. - С. 101-109.

9. Златков, М. Стъклен медальон със сцената «Рождество Христово» от Созопол / М. Злат- ков // Известия на народния музей - Бургас. T. V. Бургас : Регионален исторически музей, 2015. C. $183-189$.

10. Иванишевић, В. Римски и византијски печати и медаљони из збирке Народног музеја у Пожаревцу / В. Иванишевић // Нумизматичар. 1992. - № 15. - С. 47-52.

11. Лазарев, В. Н. Новый памятник станковой живописи XII века и образ Георгия-воина в византийском и древнерусском искусстве / В. Н. Лазарев // Лазарев, В. Н. Русская средневековая живопись. Статьи и исследования / В. Н. Лазарев. - М. : Наука, 1970. - C. 55-102.

12. Лысенко, А. В. Средневековый христианский храм на горе Пахкал-Кая в Южном Крыму / А. В. Лысенко, И. Б. Тесленко, А. Е. Мусин // В камне и в бронзе: сб. ст. в честь Анны Песковой / ред.-сост. А. Е. Мусин, О. А. Щеглова. - СПб. : ИИМК РАН : Невская Книжная типография, 2017. - С. 291-310.

13. Майко, В. В. Восточный Крым во второй половине Х - ХІІ в. / В. В. Майко. - Киев : Видавець Олег Філюк, 2014. - 467 с.

14. Макаров, Н. А. Христианская металлопластика Суздальской земли XII-XIV вв. : Новые находки / Н. А. Макаров, И. Е. Зайцева // Нескончаемое лето : сб. ст. в честь Е. А. Рыбиной / отв. ред. и сост. В. К. Сингх. - М. ; Великий Новгород : Любавич, 2018. - С. 119-130.

15. Марковић, М. О иконографији светих ратника у источно-хришћанској уметности и о представама ових светитеља у Дечанима / М. Марковић // Зидно сликарство манастира Дечана : грађа и студије. - Београд : Српска академија наука и уметности, 1995. - С. 567-626.

16. Наследие византийского Херсона / Т. Яшаева, Е. Денисова, Н. Гинькут, В. Залесская, Д. Журавлев. - Севастополь : Телескоп ; Остин : ИКА Техас. ун-та, 2011. -708 с.

17. Науменко, В. Е. «Латиняне» на Мангупе. Уникальный западноевропейский крест-энколпион из раскопок княжеского дворца Мангупского городища : Проблемы атрибуции и датировки / В. Е. Науменко // Вестник Волгоградского государственного университета. Серия 4, История. Регионоведение. Международные отношения. -2020. - Т. 25, № 6. - С. 100115. - DOI: https://doi.org/10.15688/jvolsu4.2020.6.7.

18. Науменко, В. Е. Об исторической топографии и политико-административном статусе Мангупа в золотоордынский период / В. Е. Науменко // Оазисы Шелкового пути: исторические истоки интеграционных процессов в Евразии : материалы VI Междунар. Золотоордынского Форума «Рах Tatarica : Генезис и наследие государственности Золотой Орды», круглого стола «Via Tatarica : 3олотая Орда на Великом Шелковом пути» / сост. и отв. ред. И. М. Миргалеев. - М. ; Казань : Ин-т ис- 
тории им. Ш. Марджани АН РТ : Исламская книга, 2020. - С. 232-249.

19. Науменко, В. Е. Основные этапы истории христианской общины Мангупа. Новые материалы исторических и архитектурно-археологических исследований / В. Е. Науменко, А. Г. Герцен, Д. В. Иожица // XXII Боспорские чтения «Боспор Киммерийский и варварский мир в период античности и средневековья. Новые открытия, новые проекты» : материалы Междунар. науч. конф. / ред.-сост. В. Н. Зинько, Е. А. Зинько. - Симферополь ; Керчь : НИЦИАК КФУ : ИАК РАН: ЦАИБФ «Деметра», 2021. - С. 278-290.

20. Науменко, В. Е. Уникальная византийская костяная иконка из раскопок Мангупского городища / В. Е. Науменко, А. А. Душенко // Материалы по археологии, истории и этнографии Таврии. 2019. - Вып. XXIV. - С. 217-249.

21. Науменко, В. Е. Церковь Святого Георгия / В. Е. Науменко, Д. В. Иожица, А. И. Набоков // Герцен, А. Г. Население Дороса-Феодоро по результатам комплексного археолого-антропологического анализа некрополей Мангупского городища (IVXVII вв.) : коллективная монография / А. Г. Герцен, В. Е. Науменко, Т. Ю. Шведчикова ; под ред. А. И. Айбабина. - М. ; СПб. : Нестор-История, 2017. - С. 56-108.

22. Соболев, В. Ю. Иконки-привески с конным изображением Святого Георгия / В. Ю. Соболев // В камне и в бронзе : сб. ст. в честь Анны Песковой / ред.-сост. А. Е. Мусин, О. А. Щеглова. - СПб. : ИИМК РАН : Невская Книжная типография, 2017. C. 537-547.

23. Соболев, В. Ю. Раннесредневековые древнерусские иконки-привески. Образцы и подражания / В. Ю. Соболев // Актуальные проблемы теории и истории искусства : сб. науч. ст. Вып. 9 / под ред. А. В. Захаровой, С. В. Мальцевой, Е. Ю. Станюкович-Денисовой. - М. ; СПб. : НППринт, 2019. - С. 429-438.

24. Соболев, В. Ю. Святой Георгий. Иконография одного типа иконок и снаряжение всадника и коня XII-XIII вв. / В. Ю. Соболев // История военного костюма: От древнего мира до наших дней : материалы II Междунар. военно-ист. конф. / под ред. А. В. Арановича, Д. Ю. Алексеева. - СПб. : СПбГУПТД, 2017. - С. 29-50.

25. Спиргис, Р. Находки иконок с изображением св. Георгия на территории Латвии / Р. Спиргис // Археология и история Пскова и Псковской области. - 2019. - № 34 (64). - С. 314-334.

26. Станюкович, А. К. Неизвестные памятники русской металлопластики. Миниатюрные иконкипривески XI-XVI вв. / А. К. Станюкович. - М. : Группа «ИскателИ», 2011. - 224 с.

27. Степаненко, В. П. К иконографии святых воинов-всадников в византийской сфрагистике :
Св. Георгий / В. П. Степаненко // Античная древность и средние века. - 2019. - Т. 47. - С. 72-82.

28. Степаненко, В. П. К иконографии фрески храма «Трех всадников» под Эски-Керменом / В. П. Степаненко // Материалы по археологии, истории и этнографии Таврии. - 2003. - Вып. Х. - С. 452-457.

29. Степаненко, В. П. Образ святого Георгиявсадника в византийской и древнерусской сфрагистике домонгольского периода / В. П. Степаненко // Проблемы истории России : сб. науч. тр. Вып. 3 : Новгородская Русь : Историческое пространство и культурное наследие. - Екатеринбург : Банк культурной информации, 2000. - С. 106-117.

30. Тотев, К. Средневековые византийские свинцовые иконы из Северо-Восточной Болгарии (к иконографии Святого Георгия-драконоборца) / К. Тотев // Материалы по археологии, истории и этнографии Таврии. - 2000. Вып. VII. - С. 362-369.

31. Турова, Н. П. Средневековый пещерный комплекс хребта Иограф над г. Ялтой / Н. П. Турова // Материалы по археологии и истории античного и средневекового Крыма. - 2014. - Вып. 6. - С. 93-173.

32. Хайрединова, Э. А. Медальоны с изображением святого всадника из могильника у с. Лучистое / Э. А. Хайрединова // Материалы по археологии, истории и этнографии Таврии. - 2014. Вып. ХІХ. - С. 147-210.

33. Чукова, Т. А. Иконография Христа, Божией Матери и святых на древнерусских металлических актовых печатях X-XV вв. / Т. А. Чукова // Христианская иконография Востока и Запада в памятниках материальной культуры Древней Руси и Византии : Памяти Т. Чуковой. - СПб. : Петербургское востоковедение, 2006. - С. 28-77.

34. Чуракова, А. Ю. Подвеска-иконка «Чудо св. Георгия о Змие» с городища близ Шепетовки / А. Ю. Чуракова // В камне и в бронзе : сб. ст. в честь Анны Песковой / ред.-сост. А. Е. Мусин, О. А. Щеглова. - СПб. : ИИМК РАН ; Невская Книжная типография, 2017. - С. 611-614.

35. Чуракова (Кононович), А. Ю. Привески-образки с изображением святого всадника на территории Древнерусского государства / А. Ю. Чуракова (Кононович) // Археология и история Пскова и Псковской области. - 2016. - № 31 (61). - С. 367-374.

36. Шандровская, В. С. Образ святого Георгия на византийских печатях / В. С. Шандровская // Византийская сфрагистика в трудах В. С. Шандровской / под ред. Е. В. Степановой. - СПб. : Изд-во Гос. Эрмитажа, 2019. - C. 474-480.

37. Foskolou, V. Glass Medallions with Religious Themes in the Byzantine Collection at the Benaki Museum: A Contribution to the Study of Pilgrim Tokens in Late Middle Ages / V. Foskolou // Movбcío Млєvóкๆ. - 2005. - № 4 (2004). - P. 51-73. 
38. Grotowski, P. Ł. Arms and Armour of the Warrior Saints. Tradition and Innovation in Byzantine Iconography (843-1261) / P. Ł. Grotowski. - Leiden ; Boston : Brill, 2010. - 483 p.

39. Walter, Ch. The Warrior Saints in Byzantine Art and Tradition / Ch. Walter. - London ; New York : Routledge, 2016. - 317 p.

40. White, M. Military Saints in Byzantium and Rus, 900-1200 / M. White. - Cambridge : Cambridge University Press, 2013. - $255 \mathrm{p}$.

41. Żółkowska, J. Przyczynek do badań nad wczesnośredniowiecznymi zawieszkami z wizerunkami przypisywanymi św. Jerzemu. Znaleziska z obszaru Polski / J. Żółkowska // Materiały i sprawozdania Rzeszowskiego Ośrodka Archeologisznego. - 2016. T. XXXVII. - S. 247-278.

\section{REFERENCES}

1. Alpatov M.V. Obraz Georgiya-voina v iskusstve Vizantii i Drevney Rusi [The Image of George the Warrior in the Art of Byzantium and Old Rus]. Trudy Otdela drevnerusskoy literatury [Proceedings of the Department of Old Russian Literature], 1956, vol. 12, pp. 292-310.

2. Arkhipova E.I. Kamennye ikonki so svyatymi voinami: Vizantiyskoe nasledie i yuzhnorusskaya traditsiya [Small Stone Icons with Warrior Saints: The Byzantine Heritage and the Southern Russian Tradition]. Trudy Gosudarstvennogo Ermitazha [Proceedings of the State Hermitage], 2015, vol. 74: Vizantiya $v$ kontekste mirovoy kultury: materialy konf., posvyashchennoy pamyati A.V. Bank (19061984) [Byzantium Within the Context of the World Culture. Collection of Scientific Papers Dedicated to the Memory of A.V. Bank (1906-1984)], pp. 271-289.

3. Atanasov G. Sveti Georgi Pobedonosets. Kult i obraz v pravoslavniya Iztok prez srednovekovieto [Saint George Triumphant. The Cultus and Image in the Medieval Eastern Orthodox World]. Varna, Zograf Publ., 2001. 443 p.

4. Gertsen A.G., Yashaeva T.Yu. Drevnerusskie enkolpiony iz Yugo-Zapadnogo Kryma [Ancient Rus' Reliquary Crosses from South-West Crimea]. Peskova A.A., Shcheglova O.A., Musin A.E., eds. Slavyano-russkoe yuvelirnoe delo i ego istoki: materialy Mezhdunar. nauch. konf., posvyash. 100letiyu so dnya rozhdeniya G.F. Korzuhinoy [Slavic and Old Russian Art of Jewelry and Its Roots. Proceedings of International Scientific Conference Dedicated to the $100^{\text {th }}$ Anniversary of G.F. Korzukhina's Birth]. Saint Petersburg, Nestor-Istoriya Publ., 2010, pp. 355-362.

5. Gertsen A.G., Naumenko V.E. «Mezhdu Zolotoy Ordoy i Romaniey...». Velikokhanskiy vektor v culture regionalnykh elit ili $\mathrm{k}$ voprosu o zolotoordynskom periode $\mathrm{v}$ istorii Mangupa serediny - vtoroy poloviny XIV v. (obzor arkheologicheskikh istochnikov) ["Between the Golden Horde and Romania...". The Great Khan Vector in the Culture of Regional Elites or the Question of the Golden Horde Period in the History of Mangup in the Middle - the Second Half of the $14^{\text {th }}$ Century (Review of Archaeological Sources)]. Krym v zolotoordynskiy period. Krymskiy Yurt Zolotoy Ordy: Nasledie ischeznuvshey imperii: katalog vystavki [Crimea During the Golden Horde Period. Crimean Yurt of the Golden Horde: The Heritage of a Vanished Empire. Exhibition Catalog]. Simferopol, Tarpan Publ., 2016, pp. 36-49.

6. Gertsen A.G., Naumenko V.E., Dushenko A.A. Knyazheskiy dvorets Mangupskogo gorodishcha. Stratigrafiya uchastka issledovaniy 2006-2017 gg. (predvaritelnoe soobshchenie) [Prince's Palace at the Ancient City of Mangup. Stratigraphy of the 20062017 Research Area (Preliminary Communication)]. Alekseenko N.A., ed. XMezhdunarodnyy Vizantiyskiy seminar "Chersōnos themata: Imperiya $i$ polis». materialy nauch. konf. [The $10^{\text {th }}$ International Byzantine Seminar "Chersonos themata: 'Empire' and 'Polis"'. Proceedings of the Scientific Conference]. Sevastopol, IAK RAN Publ., 2018, pp. 53-58.

7. Gertsen A.G., Naumenko V.E., Dushenko A.A. Osnovnye itogi i perspektivy issledovaniy knyazheskogo dvortsa Mangupskogo gorodishcha [The Main Results and Prospects of Research of the Princely Palace of the Mangup Settlement]. Zinko V.N., Zinko E.A., eds. XX Bosporskie chteniya «Bospor Kimmeriyskiy $i$ varvarskiy mir $v$ period antichnosti $i$ srednevekovya. Osnovnye itogi $i$ perspektivy issledovaniy»: materialy Mezhdunar. nauch. konf. [The $20^{\text {th }}$ Bosporan Readings. Cimmerian Bosporus and the World of the Barbarians in Antiquity and the Middle Ages. Main Results and Prospects of Research. Proceedings of International Scholarly Conference]. Simferopol, Kerch, NITs IAK KFU; TsAI BF «Demetra» Publ., 2019, pp. 139-148.

8. Dushenko A.A. Metallicheskie zerkala iz raskopok Mangupskogo knyazheskogo dvortsa [Metal Mirrors from the Excavations of the Prince's Palace of Mangup]. Zinko V.N., Zinko E.A., eds. XXI Bosporskie chteniya "Bospor Kimmeriyskiy $i$ varvarskiy mir v period antichnosti i srednevekovya. Obekty iskusstva v arkheologicheskom kontekste": materialy Mezhdunaodnoy nauchnoy konferentsii [The $21^{\text {st }}$ Bosporan Readings. Cimmerian Bosporus and the World of the Barbarians in Antiquity and the Middle Ages. Objects of Art in an Archaeological Context. Proceedings of International Scholarly Conference]. Simferopol, Kerch, NITs IAK KFU; IAK RAN; TsAI BF «Demetra» Publ., 2020, pp. 101-109.

9. Zlatkov M. Staklen medalon sas stsenata «Rozhdestvo Khristovo» ot Sozopol [Glass Medallion 
with Nativity Scene from Sozopol]. Izvestiya na narodniya muzey - Burgas [Bulletin of the National Museum in Burgas]. Burgas, Regionalen istoricheski muzey, 2015, vol. 5, pp. 183-189.

10. Ivanisheviж V. Rimski i vizantijski peиati i medaljoni iz zbirke Narodnog muzeja u Poharevcu [Roman and Byzantine Seals and Medallions from the National Museum Collection in Poharevac]. Numizmatichar [Numismatics], 1992, no. 15, pp. 47-52.

11. Lazarev V.N. Novyy pamyatnik stankovoy zhivopisi XII veka i obraz Georgiya-voina v vizantiyskom i drevnerusskom iskusstve [A New Monument of Easel Painting of the $12^{\text {th }}$ Century and the Image of St. George the Warrior in Byzantine and Old Rus Art]. Lazarev V.N. Russkaya srednevekovaya zhivopis. Statyi i issledovaniya [Russian Medieval Painting. Articles and Research]. Moscow, Nauka Publ., 1970, pp. 55-102.

12. Lysenko A.V., Teslenko I.B., Musin A.E. Srednevekovyy khristianskiy khram na gore PakhkalKaya v Yuzhnom Krymu [Medieval Christian Church on the Mount Pakhkal-Kaya in Southern Crimea]. Musin A.E., Shcheglova O.A., eds. Vkamne i v bronze: sb. st. $v$ chest Anny Peskovoy [In Stone and Bronze. Essays Presented in Honor of Anna Peskova]. Saint Petersburg, IIMK RAN; Nevskaya Knizhnaya tipografiya, 2017, pp. 291-310.

13. Mayko V.V. Vostochnyy Krym vo vtoroy polovine $X-X I I v$. [Eastern Crimea in the Second Half of the $10^{\text {th }}-12^{\text {th }}$ Century]. Kiev, Vydavets Oleg Filiuk Publ., 2014. 467 p.

14. Makarov N.A., Zajceva I.E. Khristianskaya metalloplastika Suzdalskoy zemli XII-XIV vv.: Novye nakhodki [Christian Metal-Plastic Works of the Suzdal Land of the $12^{\text {th }}-14^{\text {th }}$ Centuries: New Findings]. Singh V.K., ed. Neskonchaemoe leto: sb. st. $v$ chest E.A. Rybinoy [Endless Summer. Collection of Articles in Honor of E.A. Rybina]. Moscow, Veliky Novgorod, Lyubavich Publ., 2018, pp. 119-130.

15. Marković M. O ikonografiji svetih ratnika u istočno-hrišćanskoj umetnosti i o predstavama ovih svetitelja u Dečanima [On the Iconography of the Military Saints in Eastern Christian Art and the Representations of Holy Warriors in the Monastery of Dečani]. Zidno slikarstvo manastira Dečana: građa i studije [Mural Painting of Monastery of Dečan]. Beograd, Srpska akademija nauka i umetnosti, 1995, pp. 567-626.

16. Yashaeva T., Denisova E., Ginkut N., Zalesskaya V., Zhuravlev D. Nasledie vizantiyskogo Khersona [The Legacy of Byzantine Cherson]. Sevastopol, Teleskop Publ.; Austin, IKA Tekhasskogo universiteta, 2011. 708 p.

17. Naumenko V.E. «Latinyane» na Mangupe. Unikal'nyy zapadnoevropeyskiy krest-enkolpion iz raskopok knyazheskogo dvortsa Mangupskogo gorodishcha: problemy atributsii i datirovki [The "Latins" on Mangup. Unique Western-European Cross-Encolpion from the Excavations of Prince's Palace in Ancient Mangup: Problems of Attribution and Dating]. Vestnik Volgogradskogo gosudarstvennogo universiteta. Seriya 4. Istoriya. Regionovedenie. Mezhdunarodnye otnosheniya [Science Journal of Volgograd State University. History. Area Studies. International Relations], 2020, vol. 25 , no. 6 , pp. 100115. DOI: https://doi.org/10.15688/jvolsu4.2020.6.7.

18. Naumenko V.E. Ob istoricheskoy topografii i politiko-administrativnom statuse Mangupa $\mathrm{v}$ zolotoordynskiy period [About the Historical Topography and Political and Administrative Status of Mangup in the Golden Horde Period]. Mirgaleev I.M., ed. Oazisy Shelkovogo puti: istoricheskie istoki integratsionnykh protsessov $v$ Evrazii: materialy VI Mezhdunar. Zolotoordynskogo Foruma «Pax Tatarica: Genezis i nasledie gosudarstvennosti Zolotoy Ordy», kruglogo stola "Via Tatarica: Zolotaya Orda na Velikom Shelkovom puti» [Oases of the Silk Road: The Historical Origins of Integration Processes in Eurasia. Proceedings of the $6^{\text {th }}$ International Golden Horde Forum "Pax Tatarica: Genesis and Legacy of the Statehood of the Golden Horde", Round Table "Via Tatarica: Golden Horde on the Great Silk Road"]. Moscow; Kazan, Institut istorii im. Sh. Mardzhani AN RT; Islamskaya kniga Publ., 2020, pp. 232-249.

19. Naumenko V.E., Gertsen A.G., Iozhica D.V. Osnovnye etapy istorii khristianskoy obshchiny Mangupa. Novye materialy istoricheskikh i arkhitekturno-arheologicheskikh issledovaniy [The Main Stages of the History of the Christian Community of Mangup. New Materials of Historical, Architectural and Archaeological Research]. Zinko V.N., Zinko E.A., eds. XXII Bosporskie chteniya "Bospor Kimmeriyskiy $i$ varvarskiy mir v period antichnosti i srednevekovya. Novye otkrytiya, novye proekty": materialy Mezhdunar. nauch. konf. [The $22^{\text {nd }}$ Bosporan Readings. Cimmerian Bosporus and the World of the Barbarians in Antiquity and the Middle Ages. New Discoveries, New Projects. Proceedings of International Scholarly Conferemce]. Simferopol, Kerch, NITs IAK KFU; IAK RAN; TsAI BF «Demetra» Publ., 2021, pp. 278-290.

20. Naumenko V.E., Dushenko A.A. Unikalnaya vizantiyskaya kostyanaya ikonka iz raskopok Mangupskogo gorodishcha [A Unique Byzantine Bone Icon Excavated at the Ancient Town of Mangup]. Materialy po arkheologii, istorii $i$ etnografii Tavrii [Materials in Archaeology, History and Ethnography of Tauria], 2019, iss. 24, pp. 217-249.

21. Naumenko V.E., Iozhica D.V., Nabokov A.I. Tserkov Svyatogo Georgiya [Church of St. George]. Gertsen A.G., Naumenko V.E., Shvedchikova T.Yu. Naselenie Dorosa-Feodoro po rezultatam 
kompleksnogo arkheologo-antropologicheskogo analiza nekropoley Mangupskogo gorodishcha (IVXVII vv.): kollektivnaya monografiya [The Population of Doros-Feodoro According to the Results of a Comprehensive Archaeological and Anthropological Analysis of the Necropolises of the Mangup Settlement ( $4^{\text {th }}-17^{\text {th }}$ Centuries). Collective Monograph]. Moscow, Saint Petersburg, Nestor-Istoriya Publ., 2017, pp. 56-108.

22. Sobolev V.Yu. Ikonki-priveski s konnym izobrazheniem Svyatogo Georgiya [Icon Pendants with the Image of Saint Georgeon Horseback]. Musin A.E., Shcheglova O.A., eds. V kamne i $v$ bronze: sb. st. $v$ chest Anny Peskovoy [In Stone and Bronze. Essays Presented in Honor of Anna Peskova]. Saint Petersburg, IIMK RAN; Nevskaya Knizhnaya tipografiya, 2017, pp. 537-547.

23. Sobolev V.Yu. Rannesrednevekovye drevnerusskie ikonki-priveski. Obraztsy i podrazhaniya [Early Medieval Old Rus' Pendant Icons. Models and Imitations]. Zakharova A.V., Maltseva S.V., Stanyukovich-Denisova E.Yu., eds. Aktualnye problemy teorii i istorii iskusstva: sb. nauch. st. [Actual Problems of Theory and History of Art. Collection of Scientific Articles]. Moscow, Saint Petersburg, NP-Print Publ., 2019, iss. 9, pp. 429-438.

24. Sobolev V.Yu. Svyatoy Georgiy. Ikonografiya odnogo tipa ikonok i snaryazhenie vsadnika i konya XII-XIII vv. [St. George. Iconography of One Type of Icons and Equipment of the Rider and Horse of the $12^{\text {th }}-13^{\text {th }}$ Centuries]. Aranovich A.V., Alekseev D.Yu., eds. Istoriya voennogo kostyuma: ot drevnego mira do nashikh dney. Materialy II Mezhdunar. voennoist. konf. [The History of the Military Suit: From the Ancient World to the Present Day. Proceeedings of the $2^{\text {nd }}$ International Military and History Conference]. Saint Petersburg, SPbGUPTD, 2017, pp. 29-50.

25. Spirgis R. Nakhodki ikonok s izobrazheniem sv. Georgiya na territorii Latvii [Finds of Icons with an Image of St. George in Present-Day Latvia]. Arheologiya i istoriya Pskova i Pskovskoy oblasti [Archeology and History of Pskov and Pskov Region], 2019, no. 34 (64), pp. 314-334.

26. Stanyukovich A.K. Neizvestnye pamyatniki russkoy metalloplastiki. Miniatyurnye ikonki-priveski XIXVI vv. [Unknown Monuments of Russian Metal-Plastic. Miniature Icons-Pendants of the $11^{\text {th }}-16^{\text {th }}$ Centuries]. Moscow, Gruppa «IskatelI», 2011.224 p.

27. Stepanenko V.P. K ikonografii svyatykh voinov-vsadnikov v vizantiyskoy sfragistike: Sv. Georgiy [For the Iconography of Holy Riders Warrior Saints in Byzantine Sigillography: St. George]. Antichnaya drevnost $i$ srednie veka [Antiquities and the Middle Ages], 2019, vol. 47, pp. 72-82.

28. Stepanenko V.P. K ikonografii freski khrama «Trekh vsadnikov» pod Eski-Kermenom [On Iconography of Fresco in the Church of "Three Riders" Near Eski-
Kermen]. Materialy po arkheologii, istorii i etnografii Tavrii [Materials in Archaeology, History and Ethnography of Tauria], 2003, iss. 10, pp. 452-457.

29. Stepanenko V.P. Obraz svyatogo Georgiyavsadnika $v$ vizantiyskoy i drevnerusskoy sfragistike domongolskogo perioda [The Image of St. George the Horseman in Byzantine and Old Russian Sphragistics of the Pre-Mongol Period]. Problemy istorii Rossii: sbornik nauchnykh trudov Vyp. 3: Novgorodskaya Rus: istoricheskoe prostranstvo i kulturnoe nasledie [Problems of the History of Russia: Collection of Scientific Papers. Iss. 3. Novgorod Rus: Historical Space and Cultural Heritage]. Yekaterinburg, Bank kulturnoy informatsii Publ., 2000, pp. 106-117.

30. Totev K. Srednevekovye vizantiyskie svintsovye ikony iz Severo-Vostochnoy Bolgarii (k ikonografii Svyatogo Georgiya-drakonobortsa) [Medieval Byzantine's Icons of Lead from NorthEastern Bulgaria (The Iconography of Saint George Struggle with Dragon]. Materialy po arkheologii, istorii i etnografii Tavrii [Materials in Archaeology, History and Ethnography of Tauria], 2000, iss. 7, pp. 362-369.

31. Turova N.P. Srednevekovyy peshchernyy kompleks khrebta Iograf nad g. Yaltoy [Medieval Cave Complex of Iograf Ridge over Yalta]. Materialy po arkheologii $i$ istorii antichnogo $i$ srednevekovogo Kryma [Materials in Archaeology and History of Ancient and Medieval Crimea], 2014, iss. 6, pp. 93-173.

32. Khairedinova E.A. Medalony s izobrazheniem svyatogo vsadnika iz mogilnika u s. Luchistoe [Medallions with the Image of Holy Rider from the Necropolis Near the Village of Luchistoye]. Materialy po arkheologii, istorii i etnografii Tavrii [Materials in Archaeology, History and Ethnography of Tauria], 2014, iss. 19, pp. 147-210.

33. Chukova T.A. Ikonografiya Khrista, Bozhiey Materi i svyatykh na drevnerusskikh metallicheskikh aktovykh pechatyakh X-XV vv. [Iconography of Christ, Our Lady and Saints on Ancient Russian Metallic Seals of $10^{\text {th }}-15^{\text {th }}$ Centuries]. Khristianskaya ikonografiya Vostoka i Zapada v pamyatnikakh materialnoy kultury Drevney Rusi i Vizantii: Pamyati T. Chukovoy [Christian Iconography of East and West on the Archaeological objects of Old Russia and Byzantium. In Memoriam T. Chukova]. Saint Petersburg, Peterburgskoe Vostokovedenie Publ., 2006, pp. 28-77.

34. Churakova A.Yu. Podveska-ikonka «Chudo sv. Georgiya o Zmie» s gorodishcha bliz Shepetovki [Icon Pendant with a Representation of Saint Georges Slayng the Dragon from the Fortified Site Near the Town of Shepetivka]. Musin A.E., Shcheglova O.A., eds. $V$ kamne $i v$ bronze: sb. st. v chest Anny Peskovoy [In Stone and Bronze. Essays Presented in Honor of Anna Peskova]. Saint Petersburg, IIMK RAN; Nevskaya Knizhnaya tipografiya, 2017, pp. 611-614. 
B.E. Науменко. Иконка-привеска с изображением святого Воина-всадника из раскопок Мангупского дворца

35. Churakova(Kononovich) A.Yu. Priveski-obrazki s izobrazheniem svyatogo vsadnika na territorii Drevnerusskogo gosudarstva [Pendants - Small Icons with the Image of the Holy Horseman on the Territory of Ancient Russian State]. Arheologiya i istoriya Pskova $i$ Pskovskoy oblasti [Archaeology and History of Pskov and Pskov Region], 2016, no. 31 (61), pp. 367-374.

36. Shandrovskaya V.S. Obraz svyatogo Georgiya na vizantiyskikh pechatyakh [Image of St. George on Byzantine Seals]. Stepanova E.V., ed. Vizantiyskaya sfragistika $v$ trudakh V.S. Shandrovskoy [Byzantine Sphragistics in the Works of E.V. Šandrovskaya]. Saint Petersburg, Izd-vo Gosudarstvennogo Ermitazha, 2019, pp. 474-480.

37. Foskolou V. Glass Medallions with Religious Themes in the Byzantine Collection at the Benaki Museum: A Contribution to the Study of Pilgrim Tokens in Late Middle Ages. Mouseio Mpenakē [Benaki Museum], 2005, no. 4 (2004), pp. 51-73.
38. Grotowski P.Ł. Arms and Armour of the Warrior Saints. Tradition and Innovation in Byzantine Iconography (843-1261). Leiden, Boston, Brill, 2010. $483 \mathrm{p}$.

39. Walter Ch. The Warrior Saints in Byzantine Art and Tradition. London, New York, Routledge, 2016. 317 p.

40. White M. Military Saints in Byzantium and Rus', 900-1200. Cambridge, Cambridge University Press, 2013. $255 \mathrm{p}$.

41. Żółkowska, J. Przyczynek do badań nad wczesnośredniowiecznymi zawieszkami z wizerunkami przypisywanymi św. Jerzemu. Znaleziska z obszaru Polski [Contribution to the Research on Early Medieval Pendants with Images Attributed to St. George. Findings from Poland]. Materiaty i sprawozdania Rzeszowskiego Ośrodka Archeologisznego [Materials and Reports of the Rzeszów Archaeological Center], 2016, vol. 37, pp. 247-278.

\section{Information About the Author}

Valery E. Naumenko, Candidate of Sciences (History), Associate Professor, Department of Ancient and Middle Ages History, V.I. Vernadsky Crimean Federal University, Prosp. Vernadskogo, 4, 295007 Simferopol, Russian Federation, byzance@rambler.ru, https://orcid.org/0000-0002-2590-6314

\section{Информация об авторе}

Валерий Евгеньевич Науменко, кандидат исторических наук, доцент кафедры истории древнего мира и средних веков, Крымский федеральный университет им. В.И. Вернадского, просп. Вернадского, 4, 295007 г. Симферополь, Российская Федерация, byzance@rambler.ru, https://orcid.org/0000-0002-2590-6314 